\title{
PENGARUH DISPLIN KERJA TERHADAP KINERJA PEGAWAI NEGERI SIPIL BIDANG SEKRETARIAT DINAS KEPEMUDAAN DAN OLAHRAGA PROVINSI RIAU
}

\author{
${ }^{1}$ Yogie Rahmat. ${ }^{2}$ R. Ay Nadia Gebisca \\ ${ }^{12}$ Sekolah Tinggi Ilmu Ekonomi Riau \\ E-mail: yogierahmat400@gmail.com
}

\begin{abstract}
Government Agencies is an organization in which is a collection of specially selected persons to perform the duties of the state as a form of service to the people. Goals of government agencies can be achieved if able to process, move and use human resources owned effectively and efficiently. This research was conducted at the offices of Youth and Sport Service Province Riau. The purpose of this study is to determine whether there is work discipline affect the performance of employees in the department of cooperatives and micro small and medium enterprises. In this research, sampling using sample saturated, that is as much 40 people. Results of simple linear regression obtained value $Y=5.260+1.052 X$. and result tes_t obtained value t_hitung 4,061 > t_tabel (2,02439) it can be concluded that work discipline requires a significant affect to employee performance. The amount of influence of work discipline on employee performance is 30,3 percent while the rest of 69,7 percent describes other independent variables that are not observed in this study.
\end{abstract}

Keywords: Work Discipline and Employee Performance

\section{A. PENDAhULUAN}

Faktor sumber daya manusia merupakan elemen yang harus diperhatikan oleh setiap instansi, terutama bila mengingat instansi pemerintah yang berhubungan dengan pelayanan publik. Hal ini memaksa setiap instansi harus dapat bekerja dengan lebih efektif, efisien dan produktif. Dalam pemberian pelayanan publik tentunya ini akan memacu instansi untuk dapat mempertahankan kelangsungan organisasinya dimasa yang akan datang. Hal ini membuat instansi pemerintah harus memperhatikan pada aspek sumber daya manusia. Jadi, manusia dipandang sebagai faktor penentu, sebab inovasi dapat direalisasikan melalui manusia dalam mewujudkan tujuan yang ingin dicapai.

Pegawai merupakan penggerak kegiatan dalam suatu instansi. Dalam melakukan kegiatan, pegawai memerlukan petunjuk kerja dari instansi agar pelaksanaannya sesuai dengan perencanaan dan harus didukung peraturan kerja instansi sehingga menciptakan disiplin kerja. Pelaksanaan disiplin kerja itu sendiri harus dikelola dengan baik oleh para pegawainya karena dengan kurangnya kedisiplinan para pegawai akan berdampak pada pekerjaan yang kurang baik, kurang maksimal yang mengakibatkan kinerja instansi menjadi turun. Pada dasarnya instansi pemerintah harus mengedepankan pelayanan publik. Dalam hal ini ada juga yang harus diperhatikan oleh instansi, yaitu terkait kinerja pegawai.

Dinas Kepemudaan dan Olahraga Provinsi Riau adalah salah satu instansi pemerintahan daerah yang ada dalam jajaran organisasi pemerintahan daerah Provinsi Riau. Berdasarkan Peraturan Gubernur Nomor 30 Tahun 2009 Tentang Pembentukan Susunan Organisasi, Kedudukan dan Tugas Pokok Dinas-dinas di Lingkungan Pemerintahan Provinsi Riau, dalam hal ini Dinas Kepemudaan dan Olahraga Provinsi Riau mempunyai tugas kewenangan desentralisasi bidang pemuda dan olahraga dan dapat ditugaskan untuk melaksanakan penyelenggaraan wewenang wajib yang dilimpahkan oleh pemerintah kepada gubernur selaku wakil pemerintahan dalam rangka dekonsentrasasi.

Tabel 1: Tingkat Kehadiran Pegawai Negeri Sipil Bidang Sekretariat Dinas Kepemudaan dan Olahraga Provinsi Riau dari Tahun 2014 s/d Tahun 2018

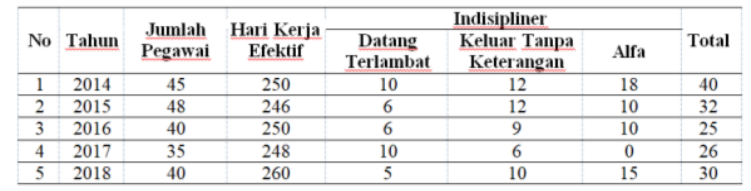
Sumber: Dari Administrasi Dinas Kepemudaan dan Olahraga Provinsi Riau, 2019 
Dari data diatas dapat dilihat bahwa masih tingginya tingkat ketidakdisiplinan pegawai pada bagian umum Dinas Kepemudaan dan Olahraga Provinsi Riau dimana tahun 2014 jumlah ketidakdisiplinan sebanyak 40 orang. Tahun 2015 jumlah ketidakdisiplinan sebanyak 32 orang. Tahun 2016 jumlah ketidakdisiplinan sebanyak 25 orang. Tahun 2017 jumlah ketidakdisiplinan sebanyak 26 orang. Tahun 2017 jumlah ketidakdisiplinan sebanyak 30 orang. Dari tingkat presentase dapat dilihat bagaimana tingkat absensi selalu berfluktuasi pegawai yang melakukan indisipliner rata-rata langsung mendapat teguran dari atasan, hal ini dilakukan sesuai dengan tingkat kedisiplinan pegawai.

Untuk dapat melihat lebih jelas bentuk kegiatan yang ada pada bagian Umum Dinas Kepemudaan dan Olahraga Provinsi Riau dan Kegiatan apa saja yang yang terlaksana dan tidak terlaksana dapat dilihat pada tabel di bawah ini:

Tabel 2: Berikut Menunjukkan Tentang

Kegiatan Di Bidang Sekretariat yang

Terealisasi \& Tidak Terealisasi Pada

Tahun 2018 Dinas Kepemudaan dan Olahraga Provinsi Riau

\begin{tabular}{|c|c|c|c|c|c|}
\hline \multirow{2}{*}{$\begin{array}{l}\mathbf{N} \\
\mathbf{0}\end{array}$} & \multirow{2}{*}{$\begin{array}{c}\text { Nama Kegiatan Tahun } \\
2018\end{array}$} & \multicolumn{2}{|c|}{$\begin{array}{c}\text { Pelaksanaan Fisik S/d } \\
\text { Desember }\end{array}$} & \multirow{2}{*}{ Terlaksana } & \multirow{2}{*}{$\begin{array}{c}\text { Tidak } \\
\text { Terlaksan }\end{array}$} \\
\hline & & Target & Realisasi & & \\
\hline 1 & $\begin{array}{l}\text { Penyediaan Jasa Surat } \\
\text { Menyurat }\end{array}$ & $100 \%$ & $100 \%$ & v & \\
\hline 2 & $\begin{array}{l}\text { Penyediaan Jasa } \\
\text { Komunikasi, Sumber } \\
\text { Daya Air Dan Listrik }\end{array}$ & $65 \%$ & $100 \%$ & v & \\
\hline 3 & $\begin{array}{l}\text { Penyediaan Jasa } \\
\text { Kebersihan Kantor }\end{array}$ & $72,5 \%$ & $95,835 \%$ & $\checkmark$ & \\
\hline 4 & $\begin{array}{l}\text { Penyediaan Jasa } \\
\text { Perbaikan Peralatan Kerja }\end{array}$ & $48,98 \%$ & $100 \%$ & $\checkmark$ & \\
\hline 5 & $\begin{array}{l}\text { Penyediaan Alat Tulis } \\
\text { Kantor }\end{array}$ & $100 \%$ & $100 \%$ & $\checkmark$ & \\
\hline 6 & $\begin{array}{l}\text { Penyediaan Barang } \\
\text { Cetakan Dan } \\
\text { Penggandaan }\end{array}$ & $50 \%$ & $100 \%$ & $\checkmark$ & \\
\hline 7 & $\begin{array}{l}\text { Penyediaan Komponen } \\
\text { Instalasi } \\
\text { Listrik/Penerangan } \\
\text { Bangunan Kantor }\end{array}$ & $100 \%$ & $100 \%$ & v & \\
\hline 8 & $\begin{array}{l}\text { Penyediaan Peralatan Dan } \\
\text { Perlengkapan Kantor }\end{array}$ & $100 \%$ & $100 \%$ & $\sqrt{ }$ & \\
\hline 9 & $\begin{array}{l}\text { Penyediaan Bahan } \\
\text { Bacaan Dan Peraturan } \\
\text { Perundang-Undangan }\end{array}$ & $100 \%$ & $100 \%$ & v & \\
\hline $\begin{array}{l}1 \\
0\end{array}$ & $\begin{array}{l}\text { Penyediaan Bahan } \\
\text { Logistik Kantor }\end{array}$ & $100 \%$ & $91,67 \%$ & $\checkmark$ & \\
\hline $\begin{array}{l}1 \\
1 \\
\end{array}$ & $\begin{array}{l}\text { Penyediaan Makanan Dan } \\
\text { Minuman }\end{array}$ & $100 \%$ & $100 \%$ & V & \\
\hline $\begin{array}{l}1 \\
2 \\
\end{array}$ & $\begin{array}{l}\text { Rapat-Rapat Koordinasi } \\
\text { Dan Konsultasi Ke Luar } \\
\text { Daerah }\end{array}$ & $100 \%$ & $95,365 \%$ & v & \\
\hline $\begin{array}{l}1 \\
3\end{array}$ & $\begin{array}{l}\text { Penyediaan Jasa } \\
\text { Keamanan Kantor }\end{array}$ & $100 \%$ & $100 \%$ & $\checkmark$ & \\
\hline $\begin{array}{l}1 \\
4 \\
\end{array}$ & $\begin{array}{l}\text { Penyediaan Jasa } \\
\text { Administrasi Kantor }\end{array}$ & $100 \%$ & $100 \%$ & v & \\
\hline $\begin{array}{l}1 \\
5\end{array}$ & $\begin{array}{l}\text { Penyediaan Jasa } \\
\text { Informasi dan Publikasi }\end{array}$ & $100 \%$ & $100 \%$ & $\checkmark$ & \\
\hline $\begin{array}{l}1 \\
6 \\
\end{array}$ & $\begin{array}{l}\text { Pengadaan Perlengkapan } \\
\text { Gedung Kantor }\end{array}$ & $100 \%$ & $100 \%$ & $\checkmark$ & \\
\hline $\begin{array}{l}1 \\
7\end{array}$ & $\begin{array}{l}\text { Pengadaan peralatan } \\
\text { gedung kantor }\end{array}$ & - & - & & $\checkmark$ \\
\hline $\begin{array}{l}1 \\
8\end{array}$ & Pengadaan Mebeleur & $100 \%$ & $100 \%$ & v & \\
\hline
\end{tabular}

Eko dan Bisnis (Riau Economics and Business Reviewe) Volume 10, Nomor 4, 27 Desember 2019

\begin{tabular}{|c|c|c|c|c|c|}
\hline $\begin{array}{l}1 \\
9\end{array}$ & $\begin{array}{l}\text { Pemeliharaan } \\
\text { rutin/berkala mobil } \\
\text { jabatan }\end{array}$ & $100 \%$ & $100 \%$ & $\checkmark$ & \\
\hline${ }_{0}^{2}$ & $\begin{array}{l}\text { Pemeliharaan } \\
\text { rutin/berkala kendaraan } \\
\text { dinas / operasional } \\
\end{array}$ & $100 \%$ & $100 \%$ & $\checkmark$ & \\
\hline $\begin{array}{l}2 \\
1\end{array}$ & $\begin{array}{l}\text { Pemeliharaan } \\
\text { rutin/berkala peralatan } \\
\text { gedung kantor }\end{array}$ & $100 \%$ & $100 \%$ & $\checkmark$ & \\
\hline $\begin{array}{l}2 \\
2\end{array}$ & $\begin{array}{l}\text { Rehabilitasi Sedang/ } \\
\text { Berat Rumah Gedung } \\
\text { Kantor }\end{array}$ & - & - & & $\checkmark$ \\
\hline $\begin{array}{l}2 \\
3 \\
\end{array}$ & $\begin{array}{l}\text { Pembinaan Fisik dan } \\
\text { Mental Aparatur }\end{array}$ & $\begin{array}{c}65,625 \\
\%\end{array}$ & $65,625 \%$ & $\checkmark$ & \\
\hline $\begin{array}{l}2 \\
4\end{array}$ & $\begin{array}{l}\text { Pendidikan dan pelatihan } \\
\text { Formal }\end{array}$ & - & - & & $\checkmark$ \\
\hline $\begin{array}{l}2 \\
5 \\
\end{array}$ & $\begin{array}{l}\text { Penyusunan laporan } \\
\text { keuangan semesteran }\end{array}$ & $100 \%$ & $100 \%$ & $\checkmark$ & \\
\hline $\begin{array}{l}2 \\
6 \\
\end{array}$ & $\begin{array}{l}\text { Penyusunan Pelaporan } \\
\text { Keuangan akhir tahun }\end{array}$ & $100 \%$ & $100 \%$ & $\checkmark$ & \\
\hline 2 & Penyusunan laporan Aset & $100 \%$ & $100 \%$ & $\checkmark$ & \\
\hline
\end{tabular}

Sumber : Administrasi Dinas Kepemudaan dan Olahraga Provinsi Riau, 2018

Dari tabel diatas dapat dijelaskan bahwa kegiatan bagian Umum Dinas Kepemudaan dan Olahraga Provinsi Riau sebanyak 27 kegiatan yang terealisasi hanya 24 karna ada 3 kegiatan dinolkan karna kena rasionalisasi pada akhir tahun 2018.

Selanjutnya, sanksi yang diterima pegawai PNS Bidang Sekretariat Dinas Kepmudaan dan Olahraga Provinsi Riau tahun 2014 sampai dengan tahun 2018, hal ini dapat dilihat pada tabel dibawah ini:

Tabel 3: Berikut menunjukkan jenis sanksi yang diberikan terhadap pegawai Dinas Kepemudaan dan Olahraga Provinsi Riau tahun 2014 sampai dengan tahun 2018

\begin{tabular}{|c|c|c|c|c|}
\hline \multirow[b]{2}{*}{ Tahun } & \multicolumn{3}{|c|}{ Pelanggaran yang dilakukan } & \multirow[b]{2}{*}{ Jumlah } \\
\hline & Sanksi Ringan & Sanksi Sedang & Sanksi Berat & \\
\hline 2014 & 22 Orang & 18 Orang & - & 40 Orang \\
\hline 2015 & 20 orang & 12 Orang & - & 32 Orang \\
\hline 2016 & 15 Orang & 10 Orang & 2 Orang & 27 Orang \\
\hline 2017 & 16 Orang & 10 Orang & 3 Orang & 29 Orang \\
\hline 2018 & 15 Orang & 15 Orang & 20 rang & 32 Orang \\
\hline
\end{tabular}

Sumber : Administrasi, Dinas Kepemudaan dan Olahraga Provinsi Riau, 2019

Keterangannya :

Sanksi ringan : Datang terlambat, Lupa Absen, Keluar tanpa Keterangan.

Sanksi Sedang : Alfa

Sanksi Berat : Tidak Masuk sama sekali selama 1 Tahun

Tabel diatas menunjukkan bahwa terdapat beberapa orang pegawai PNS Bidang Sekretariat Dinas Kepemudaan dan Olahraga Provinsi Riau yang diberikan sanksi disiplin ringan yaitu berupa Pemotongan Tunjangan 5\%, 10\% atau $15 \%$ Berdasarkan absensi Pegawainya dari SKPD kepada pelanggar. Sanksi Sedangnya

$$
\text { P.ISSN: 1410-7988 E.ISSN: 2614-123X }
$$


berupa pemotongan tunjangan Pemotongan Tunjangan 5\%, 10\% atau 15\% Berdasarkan absensi Pegawainya dan teguran lisan dari SKPD kepada pelanggar. Sanksi Beratnya berupa Tidak menerima tunjangan sama sekali.

Terkait mengenai masih rendahnya disiplin pegawai dari survey diatas maka berimbas kepada lambannya pencapaian target pekerjaan yang selama ini menjadi tugas dan fungsi dari pegawai Dinas Kepemudaan dan Olahraga Provinsi Riau. Sebagai Gambaran lambannya pencapaian target pekerjaan yang tidak terselesaikan akibat masih tingginya presentase tingkat disiplin pegawai setiap tahunnya.

\section{Manajemen Sumber Daya Manusia}

Menurut Mangkunegara dalam

Rahmat (2018:89) Manajemen sumber daya manusia merupakan suatu perencanaan, pengorganisasian, mengkoordinasikan, pelaksanaan, dan pengawasan terhadap pengadaan, pengembangan, pemberian balas jasa, pengintegrasian, pemeliharaan dan pemisahkan tenaga kerja dalam rangka mencapai tujuan organisasi. Menurut Sinambela (2016:7) manajemen sumber daya manusia sebagai suatu pengelolaan dan pendayagunaan sumber daya yang ada pada individu.

\section{Disiplin}

Manusia sebagai individu terkadang ingin hidup bebas, sehingga ia ingin melepaskan diri dari segala ikatan dan peraturan yang membatasi kegiatan dan prilakunya. Namun manusia juga merupakan mahluk sosial yang hidup di antara individuindividu lain, di mana ia mempunyai kebutuhan akan perasaan diterima oleh orang lain.

Selanjutnya Hasibuan (2017:193), menyatakan : "Kedisiplinan adalah fungsi operatif keenam dari manajemen sumber daya manusia.kedisiplinan merupakan fungsi operatif manajemen sumber daya tinggi prestasi kerja yang dapat dicapainya. Tanpa disiplin karyawan yang baik. Sulit bagi organisasi mencapai hasil yang optimal".

Eko dan Bisnis (Riau Economics and Business Reviewe) Volume 10, Nomor 4, 27 Desember 2019

\section{Indikator-Indikator Disiplin}

Menurut Rivai dalam Sinambela (2016:355) bahwa indikator disiplin kerja sebagai berikut :

a. Kehadiran. Hal ini menjadi indikator yang mendasar untuk mengukur kedisiplinan, dan biasanya pegawai memiliki disiplin kerja rendah terbiasa untuk terlambat dalam bekerja.

b. Ketaatan dalam peraturan kerja. pegawai yang taat pada peraturan kerja tidak akan melalaikan prosedur kerja dan akan selalu mengikuti pedoman kerja yang ditetapkan oleh perusahaan.

c. Ketaatan pada standar kerja. hal ini dapat dilihat melalui besarnya tanggung jawab pegawai terhadap yang diamanahkan kepadanya.

d. Tingkat kewaspadaan tinggi. Pegawai memiliki kewaspadaan tinggi akan selalu berhati-hati, penuh perhitungan dan ketelitian dalam bekerja,serta selalu menggunakan sesuatu secara efektif dan efisien.

e. Bekerja Etis. Beberapa pegawai mungkin melakukan tindakan yang tidak sopan kepelanggan atau terlibat dalam tidakan yang tidak pantas.

\section{Kinerja}

Anwar dan Armstrong (2017:189) mengatakan bahwa kinerja adalah hasil suatu proses yang mengacu dan diukur selama periode waktu tertentu berdasarkan ketentuan atau kesepakatan yang telah ditetapkan sebelumnya. Karena kinerja pegawai menurut Lembaga Administrasi Negara Republik Indonesia. Kinerja merupakan suatu kondisi yang harus diketahui dan dikonfirmasikan kepada pihak tertentu untuk mengetahui tingkat pencapaian hasil suatu instansi dihubungkan dengan visi yang diemban suatu instansi pemerintah serta mengetahui dampak positif dan negatif. Penilaian kinerja pada dasarnya merupakan faktor kunci guna mengembangkan suatu organisasi secara efektif dan efisien, karena adanya kebijakan atau program yang lebih baik atas sumber daya manusia yang ada

P.ISSN: 1410-7988 E.ISSN: 2614-123X 
dalam organisasi. Penilaian kinerja individu sangat bermanfaat bagi dinamika pertumbuhan organisasi secara keseluruhan, melalui penilaian tersebut maka dapat diketahui kondisi sebenarnya tentang bagaimana kinerja pegawai.

Menurut Kasmir (2016:197) tujuan diadakannya penilaian kinerja bagi para pegawai dapat kita ketahui dibagi menjadi sepuluh, yaitu:

a. untuk memperbaiki kualitas pekerjaan, artinya dengan melakukan penilaian terhadap kinerja, maka manajemen perusahaan akan mengetahui dimana kelemahan karyawan dan sistem yang digunakan.

b. Keputusan penempatan, bahwa bagi karyawan yang telah dinilai kinerjanya ternyata kurang mampu untuk menempati posisi sekarang, maka perlu dipindahkan ke unit atau bagian lainnya.

c. Perencanaan dan pengebangan karir, artinya bagi mereka yang mengalami peningkatan kinerja maka akan dilakukan promosi jabatan atau kepangkatan sesuai dengan peraturan perusahaan.

d. Kebutuhan latihan dan pengembangan, bahwa tujuan kinerja untuk kebutuhan pelatihan dan pengembangan maksudnya adalah bagi karyawan yang memiliki kemampuan atau keahlian yang kurang.

e. Penyesuaian kompensasi, artinya penilaian digunakan untuk kepentingan penyesuaian kompensasi adalah bagi mereka yang kinerjanya meningkat maka akan ada penyesuaian kompensasi.

f. Inventory kompetensi pegawai, bahwa perusahaan memiliki simpanan data karyawan, data-data informasi ini merupakan data dan informasi mengenai kompetensi, skill, bakat, potensi seluruh karyawan. artinya perusahaan memiliki peta tentang kekuatan dan kelemahan karyawannya.

g. Kesempatan kerja adil, dengan melakukan sistem kerja yang baik akan memberikan rasa keadilan bagi seluruh karyawan. Artinya bagi mereka yang memiliki kinerja baik, maka memperoleh balas jasa atas jerih payahnya meningkatkan kinerja.

Eko dan Bisnis (Riau Economics and Business Reviewe) Volume 10, Nomor 4, 27 Desember 2019 h. Komunikasi yang efektif, bahwa pengetahuan komunikasi yang harus diketahui harus dilakukan untuk keseluruhan karyawan.

i. Budaya kerja, artinya dengan adanya penilaian kerja maka akan terciptanya budaya yang menghargai kualitas kerja.

j. Menerapkan sanksi, bahwa disamping memberikan berbagai keuntungan bagi karyawan, penilaian kinerja juga merupakan sarana untuk memberikan hukuman atas kinerja karyawan yang menurun.

\section{Faktor-Faktor yang Mempengaruhi Kinerja}

Kinerja merupakan suatu konstruksi multi dimensi yang mencakup banyak faktor yang mempengaruhinya. Adapun faktor-faktor tersebut terdiri dari faktor intrinsik pegawai personal dan individu atau SDM.

Menurut Kasmir (2016:189) faktorfaktor yang mempengaruhi kinerja Baik hasil maupun perilaku kerja yaitu: Kemampuan dan Keahlian, Pengetahuan, Rancangan Kerja, Kepribadian, Motivasi Kerja, Kepemimpinan, Gaya Kepemimpinan, Budaya Organisasi, Kepuasan Kerja, Lingkungan Kerja, Loyalitas, Komitmen, Disiplin Kerja

\section{Indikator Kinerja}

Menurut Permendagri No 46 tahun 2011, Untuk mengukur indikator kinerja pegawai PNS dapat dilihat sebagai berikut:

1. Orientasi pelayanan. Orientasi pelayanan adalah sikap atau perilaku kerja PNS dalam memberikan pelayanan terbaik kepada yang dilayani antara lain meliputi masyarakat, atasan, rekan kerja, unit kerja terkait dan instansi lain.

2. Integritas. Integritas adalah kemampuan untuk bertindak sesuai dengan nilai, norma dan etika dalam organisasi.

3. Komitmen. Komitmen adalah Kemauan dan kemampuan untuk P.ISSN: 1410-7988 E.ISSN: 2614-123X 
menyelaraskan sikap dan tindakan PNS untuk mewujudkan tujuan organisasi dengan mengutamakan kepentingan dinas dari pada kepentingan diri sendiri, seseorang ataupun golongan.

4. Disiplin. Disiplin adalah kesanggupan Pegawai Negeri Sipil untuk mentaati kewajiban dan menghindari larangan yang ditentukan dalam peraturan perundang-undangan dan/ atau peraturan kedinasan yang apabila tidak ditaati atau dilanggar dijatuhi hukuman disiplin.

5. Kerjasama. Kerjasama adalah kemauan dan kemampuan PNS untuk bekerja sama dengan rekan sekerja, atasan, bawahan dalam unit kerjanya serta instansi lain dalam menyelesaikan suatu tugas dan tanggung jawab yang ditentukan sehingga mencapai daya guna dan hasil guna yang sebesar besarnya.

6. Kepemimpinan. Kepemimpinan adalah kemampuan dan kemauan PNS untuk memotivasi dan mempengaruhi bawahan ataupun orang lain yang berkaitan dengan bidang tugasnya demi tercapainya tujuan organisasi.

\section{Pengaruh Disiplin Terhadap Kinerja}

Sutrisno (2015:85) disiplin kerja pada karyawan (pegawai) sangat dibutuhkan karena apa yang menjadi tujuan perusahaan (organisasi) akan sukar dicapai bila tidak ada disiplin kerja. Hasibuan (2017:193), menyatakan : "Kedisiplinan merupakan fungsi operatif mnajemen sumber daya manusia yang terpenting karena semakin baik disiplin karyawan, semakin tinggi prestasi kerja yang dicapai. Tanpa disiplin karyawan yang baik, sulit bagi organisasi perusahaan mencapai hasil yang optimal.

\section{Hipotesis}

Hipotesis dalam penelitian ini diduga disiplin kerja berpengaruh signifikan terhadap Kinerja Pegawai Negeri Sipil Bidang Sekretariat Dinas Kepemudaan dan Olahraga Provinsi Riau.

Eko dan Bisnis (Riau Economics and Business Reviewe) Volume 10, Nomor 4, 27 Desember 2019

\section{METODE}

\section{Lokasi Penelitian}

Penelitian ini dilaksanakan di Kantor Dinas Kepemudaan dan Olahraga Provinsi Riau,dengan alamat Jl.Dr.Sutomo NO.114,Pekanbaru.

\section{Sumber dan jenis data}

a) Data primer, yaitu data yang diperoleh melalui pengamatan langsung ditempat penelitian dengan mengambil data yang sesuai dengan kebutuhan penelitian, baik berupa observasi, angket dan kuisioner yang akan disebarkan oleh responden dengan Pihak PNS Bidang Sekretariat Pada Dinas Kepemudaan dan Olahraga Provinsi Riau (Sugiyono, 2010:14)

b) Data Sekunder, yaitu data yang penulis peroleh dan sumber data yang ada kaitannya dengan penelitian. (Sugiyono, 2010:14) berupa data yang sudah tersedia seperti jumlah pegawai, struktur organisasi dan data lainnya yang mendukung analisa dalam penelitian ini.

\section{Populasi dan sampel}

a) Populasi, adalah Keseluruhan subjek penelitian. Apabila seseorang ingin meneliti semua elemen yang ada dalam wilayah penelitian, maka penelitiannya merupakan penelitian populasi. (Arikunto, 2010:173) Populasi yang digunakan dalam penelitian ini adalah pegawai PNS Bidang Sekretariat Dinas Kepemudaan dan Olahraga Provinsi Riau terdiri dari PNS pada tahun 2018 yang berjumlah 40 Orang.

b) Sampel, adalah sebagian atau wakil dari jumlah dan karakteristik yang dimiliki oleh populasi tersebut". Sampel merupakan bagian dari jumlah dan karakteristik yang dimiliki oleh suatu populasi yang akan diteliti. Dalam penelitian ini pengambilan sampel menggunakan sampel jenuh, yaitu jika populasi lebih kecil dari 100 orang, maka populasi dijadikan sampel, sehingga jumlah Sampel yang diteliti adalah 40 orang. Dalam penelitian ini sampel yang diambil adalah Pegawai P.ISSN: 1410-7988 E.ISSN: 2614-123X 
Bidang Sekretariat yang bekerja pada Dinas Kepemudaan dan Olahraga Provinsi Riau tahun 2018

\section{Teknik Pengumpulan Data}

a) Observasi, Observasi adalah pengamatan yang diakukan secara sengaja, sistematis mengenai fenomena social dengan gejalagejala psikis untuk kemudian dilakukan pencatatan (Subagyo, 2015:63)

b) Angket (Quisioner), Menurut Sugiyono (2016:142), mengemukakan bahwa Kuisioner Merupakan teknik pengumpulan data yang dilakukan dengan cara memberi seperangkat pertanyaan atau pernyataan tertulis kepada responden untuk dijawabnya. Bila Penelitian dilakukan pada lingkup yang tidak terlalu luas,sehingga koesioner dapat diantarkan langsung dalam waktu yang tidak terlalu lama, maka pengiriman angket tidak perlu melalui pos.

Dengan skala likert, maka variabel yang diukur dan dijabarkan menjadi indikator variabel.Kemudian indikator tersebut dijadikan sebagai variabel. Kemudian indikator tersebut dijadikan sebagai titik tolak untuk menyusun item-item instrument yang dapat berupa pernyataan dan pertanyaan. Jawaban setiap item yang menggunakan skala likert mempuyai gradiasi dan sangat positif sampai sangat negatif. (Sugiyono, 2010:107). Kemudian untuk mengetahui rata-rata jawaban responden digunakan interval kelas, interval kelas dapat dirumuskan dengan rumus:

\section{Teknik Analisis Data}

Analisis data dapat diartikan sebagai upaya data yang sudah tersedia kemudian diolah dengan statistik dan dapat digunakan untuk menjawab rumusan masalah dalam penelitian (Sujarweni, 2014:103)

\section{Analisis Deskriptif}

Arikunto (2010:282) deskriptif adalah membandingkan antara kenyataan yang sebenarnya dengan teori-teori yang ada hubungannya dengan permasalahan guna menarik suatu kesimpulan dan ditabulasikan dalam bentuk tabel-tabel distribusi frekuensi.

\section{Analisis Kuantitatif}

Untuk mengukur pengaruh dari variabel bebas (disiplin) dengan variabel terikat (kinerja) akan digunakan metode analisis regresi linear sederhana.

\section{Uji Validitas}

Validitas menunjukkan seberapa nyata suatu pengujian mengukur apa yang seharusnya diukur. Validitas berhubungan dengan ketepatan alat ukur untuk melakukan tugasnya mencapai sasaran.Pengukuran dikatakan valid jika mengukur tujuannya dengan nyata dan benar.alat ukur yang tidak valid adalah yang memberikan hasil ukurannya menyimpang dari tujuannya. Penyimpangan pengukuran ini disebut kesalahan (Error) atau varian (Hartono, 2012:144)

\section{Uji Reliabilitas}

Uji Reliabilitas berguna untuk menetapkan apakah instrumen yang dalam hal ini kuisioner dapat digunakan lebih dan satu kali, paling tidak oleh responden yang sama akan menghasilkan data yang konsisten. Dengan kata lain, Reliabilitas instrumen mencirikan tingkat konsistensi.Nilai konsistensi reliabilitas yang baik adalah diatas 0,6 (sangat kuat). (Sugiyono, 2010:214)

\section{Regresi Linear Sederhana}

Analisis regresi sederhana adalah analisis untuk mengukur besarnya pengaruh antara satu variabel independen dengan satu variabel dependen. Analisis ini digunakan untuk mengetahui arah hubungan antara variabel independen dengan variabel dependen apakah positif atau negatif dan untuk memprediksikan nilai dari variabel dependen apabila nilai variabel independen mengalami kenaikan atau penurunan.

Data yang digunakan biasanya berskala interval atau rasio.Rumus regresi 
linear sederhana menurut (Sugiyono, 2010:270) adalah sebagai berikut:

$$
\mathrm{Y}=\mathrm{a}+\mathrm{bX}
$$

Keterangan :

$\mathrm{Y} \quad=$ Kinerja Pegawai

a $=$ Harga $\mathrm{Y}$ apabila $\mathrm{X}=0$ ( harga konstan)

$\mathrm{b} \quad=$ Koefisien regresi

$\mathrm{X}=$ Disiplin Kerja

\section{Uji t}

Uji $t$ digunakan untuk menguji signifikan hubungan antara variabel bebas dan vaiabel terikat, apakah Variabel $\mathrm{X}$ (Disiplin Kerja) benar- benar berpengaruh terhadap Variabel Y (Kinerja Pegawai). Secara terpisah atau parsial pengujian ini dilakukan dengan membandingkan $t$ yang akan dapat dari perhitungan dengan nilai $t$ yang ada pada tabel $t$ dengan tingkat kesalahan (a) sebesar 5\% dari derajat kebesaran atau degree of freedom (dt) sebesar $\mathrm{df}=\mathrm{n}-\mathrm{k}$ dengan kriteria pengambilan keputusan sebagai berikut:

a. Jika thitung >ttabel, maka $\mathrm{H}_{0}$ ditolak dan $\mathrm{H}_{\alpha}$ diterima

Berarti hipotesa diterima, maksudnya ada pengaruh yang positif dan berarti/signifikan antara Disiplin Kerja terhadap Kinerja Pegawai.

b. Jika thitung<ttabel, maka $\mathrm{H}_{0}$ diterima dan $\mathrm{H}_{\alpha}$ ditolak

Berarti hipotesa ditolak maksudnya tidak ada pengaruh yang positif dan berarti /signifikan antara Disiplin Kerja terhadap Kinerja Pegawai. Untuk mengetahui signifikan antara variabel dapat digunakan rumus uji-t, (Sugiyono, 2012:230)

$t=\frac{r_{x y} \sqrt{n-2}}{\sqrt{1-\left(r_{x y}\right)^{2}}}$

Dengan taraf signifikan 5\% uji dua pihak dan $\mathrm{dk}=\mathrm{n}-2$

Keterangan:

a. Bila thitung >ttabel, maka ada hubungan signifikan antara variabel $\mathrm{x}$ dan y.

b. Bila thitung<ttabel, maka tidak ada hubungan signifikan antara variabel $\mathrm{x}$ dan y.

Eko dan Bisnis (Riau Economics and Business Reviewe) Volume 10, Nomor 4, 27 Desember 2019
Koefisien Determinasi $\left(\mathbf{R}^{\mathbf{2}}\right)$

Uji Determinasi $\left(\mathrm{R}^{2}\right)$ dalam regresi linier digunakan untuk mengetahui persentase sumbangan pengaruh variabel bebas terhadap variabel terikat berikut rumus koefisien determinasi $\left(\mathrm{R}^{2}\right)$ adalah sebagai berikut (Sanusi, 2011:136) $R^{2}=\frac{S S R}{S S T}$

Dimana:

$\begin{array}{ll}\mathrm{R}^{2}= & \text { Determinasi } \\ \mathrm{SSR}= & \text { Keragaman Regresi } \\ \mathrm{SST} & =\quad \text { Keragaman Total }\end{array}$

HASIL

Tabel 4: Hasil Regresi Linier Sederhana

\begin{tabular}{|c|c|c|c|c|c|c|}
\hline \multicolumn{7}{|c|}{ Coefficients } \\
\hline \multirow{2}{*}{\multicolumn{2}{|c|}{ Model }} & \multicolumn{2}{|c|}{$\begin{array}{l}\text { Unstandardized } \\
\text { Coefficients }\end{array}$} & \multirow{2}{*}{$\begin{array}{c}\begin{array}{c}\text { Standardized } \\
\text { Coefficients }\end{array} \\
\text { Beta } \\
\end{array}$} & \multirow[b]{2}{*}{$\mathrm{t}$} & \multirow[b]{2}{*}{ Sig. } \\
\hline & & $\mathrm{B}$ & Std. Error & & & \\
\hline \multirow[t]{2}{*}{1} & (Constant) & 5.260 & 10.276 & & .512 & .612 \\
\hline & Disiplin & 1.052 & .259 & .550 & 4.061 & .000 \\
\hline
\end{tabular}

Sumber : Hasil Olahan Data Responden 2018

Berdasarkan tabel 5.30 diperoleh persamaan regresi linier sederhana adalah sebagai berikut : $\mathrm{Y}=5.260+1.052 \mathrm{X}$. Persamaan tersebut dapat diartikan sebagai berikut :

1. Konstanta sebesar 5.260 artinya jika disiplin kerja bernilai nol, maka kinerja pegawai PNS Bidang Sekretariat di Dinas Kepemudaan dan Olahraga Provinsi Riau sebesar 5.260 satuan.

2. Nilai koefisien regresi sebesar 1.052, artinya jika variabel disiplin kerja semakin baik atau meningkat satusatuan, maka kinerja pegawai PNS Bidang Sekretariat di Dinas Kepemudaan dan Olahraga Provinsi Riau akan meningkat sebesar 1.052 satuan.

Berdasarkan uji_t dilakukan untuk membandingkan nilai thitung dengan ttabel pada dignifikan $5 \%$ atau $(0,025)$. Dengan derajat kebebasan $(\mathrm{dt})=40-2=38$. Maka hasil yang diperoleh untuk ttabel 2,02439. Berdasarkan hasil uji regresi menunjukkan 
bahwa thitung variabel disiplin sebesar 4,061 sedangkan nilai ttabel sebesar 2,024 sehingga thitung >ttabel $(4,061>2,024)$. Dengan demikian dapat disimpulkan bahwa variabel disiplin berpengaruh positif dan signifikan terhadap variabel kinerja pegawai PNS Bidang Sekretariat Pada Dinas Kepemudaan dan Olahraga Provinsi Riau.

Tabel 5: Hasil Koefesien Determinasi

\begin{tabular}{|l|r|r|rrr}
\hline \multicolumn{5}{|c}{ Model Summary } \\
\hline Model & \multicolumn{1}{|c|}{ R } & R Square & Adjusted R Square & Std. Error of the Estimate \\
\hline 1 & $.550^{2}$ & .303 & 284 & 7.685 \\
\hline
\end{tabular}

Sumber : Hasil Olahan Data Responden 2018

Hasil koefesien determinasi sebesar 0.303 yang memiliki arti bahwa besarnya pengaruh variable bebas (disiplin kerja) terhadap variable terikat (kinerja pegawai) yaitu sebesar 30,3\% sedangkan sisanya sebesar $69.7 \%$ dipengaruhi oleh variabel lain yang tidak termasuk dalam penelitian ini.

\section{SIMPULAN}

Berdasarkan hasil dan pembahasan, maka adapun Kesimpulan dalam penelitian ini adalah :

a. Hasil rata-rata jawaban responden untuk variable disiplin kerja adalah sebesar 3.93 menyatakan setuju, dan hasil ratarata jawaban responden untuk variabel kinerja pegawai adalah sebesar 4.02 menyatakan setuju, bahwa untuk meningkatkan hasil kerja sangat didukung oleh disiplin kerja pegawai.

b. Hasil regresi linier sederhana, yaitu $\mathrm{Y}=$ $5.260+1.052 \mathrm{X}$. memiliki arti bahwa setiap ada kenaikan pada variabel disiplin kerja sebesar 1satuan, maka dapat meningkatkan kinerja pegawai.

c. Hasil Uji_t, diperoleh bahwa nilai t_hitung lebih besar dari nilai t_tabel $(4,061>2,02439)$, maka Hal ini berarti bahwa variable disiplin kerja mempunyai pengaruh yang signifikan terhadap kinerja pegawai.

Hasil koefesien determinasi sebesar 0.303 yang memiliki arti bahwa besarnya pengaruh variable bebas (disiplin kerja) terhadap variable terikat (kinerja pegawai) yaitu sebesar $30,3 \%$ sedangkan sisanya sebesar $69.7 \%$ dipengaruhi oleh

Eko dan Bisnis (Riau Economics and Business Reviewe) Volume 10, Nomor 4, 27 Desember 2019 variabel lain yang tidak termasuk dalam penelitian ini.

\section{DAFTAR RUJUKAN}

Arikunto, Suharsimi. 2010. Prosedur penelitian, Edisi Revisi. RinekaCipta : Jakarta

Arikunto, Suharsimi. 2010. Prosedur penelitian, Edisi Revisi. RinekaCipta : Jakarta

Anwar, Yonhy. 2017.Manajemen Sumber Daya Manusia.Bandung : Alfabeta

Fadel, Muhammad. 2009. Reinventing Local Government. PT. Gramedia Jakarta : Gorontalo

Fahmi, Irham. 2016. Manajemen Sumber Daya Manusia. Bandung : Alfabeta

Fauziawati, Asti. (2013). Skripsi :Pengaruh Disiplin Kerja Terhadap Kinerja Karyawan" Survei pada Karyawan Direktorat Surat dan Paket PT. Pos Indonesia (Persero) Bandung. Universitas Riau.

Hasibuan. 2017. Manajemen Sumber Daya Manusia. Jakarta : Bumi Aksara

Joko Sarwanto. (2007). Skripsi: Pengaruh Disiplin Kerja Terhadap Kinerja Karyawan Di Kantor Departemen Agama Kabupaten Karanganyar. Universitas Islam Negeri Sunan Kalijaga Yogyakarta.

Kasmir.2016. Manajemen Sumber Daya Manusia. Jakarta :Rajawali Pers

Marwansyah. 2014. Manajemen Sumber Daya Manusia.Alfabeta: Bandung

Ma'arif, Syamsul. 2012. Manajemen Kinerja Sumber Daya Manusia. IPB Press: Bogor

Mangkunegara,A.A. Anwar Prabu. 2011. Manajemen Sumber Daya Manusia Perusahaan. PT. Remaja Rosda karya : Bandung.

Notoatmodjo, $\quad$ Soekidjo. 2009. Pengembangan Sumber Daya Manusia. Jakarta :Rineka Cipta.

Prabu, Anwar.2013. Manajemen Sumber Daya Manusia. Bandung : Rosda

Rahmat, Yogie. 2018. Pengaruh Tingkat Pendidikan, Motivasi Kerja, Dan 
Disiplin Kerja Terhadap Kinerja Guru di SMPN I Kecamatan Pangkalan Koto Baru Kabupaten 50 Kota. Jurnal: Daya Saing Vol. 4, No. 1 Feb 2018

Sanusi, Anwar.2011. Metode Penelitian Bisnis. Salemba Empat : Jakarta Sujarweni,Wiratna,2014.Metode Penelitian. Pustaka baru pres:Yogyakarta

Samsilis Depra. (2017). Skripsi :Pengaruh Disiplin Kerja Terhadap Kinerja Pegawai Dinas Kopersi dan Usaha Micro Kecil dan Menengah Kabupaten Pelalawan. Sekolah Tinggi Ekonomi Riau,Pekanbaru

Sunyoto, Danang . 2015. Penelitian Sumber Daya Manusia.Yogyakarta : CAPS

Sugiyono. 2010. Metode Penelitian Administrasi, Cetakan XVIII. Alfabeta. Bandung

Sugiyono.2016. Metode Penelitian. Bandung : Alfabeta

Sinambela, lijan Poltak. 2016. Manajemen Sumber Daya Manusia. Bumi Aksara: Jakarta

Sutrisno, Edy. 2013. Budaya Organisasi dan Peningkatan Kinerja Perusahaan .BumiAksara : Jakarta

Tika, Moh, Pabundu,2010.Budaya Organisasi dan Peningkatan Kinerja Perusahaan. Bumi Aksara : Jakarta

Umar, Husein. 2013.Metode Penelitian untuk Skripsi dan -Tesis.Rajawali: Jakarta. 